\title{
Learning How to Design Apps through the Cognitive Apprenticeship Approach and Collaborative Learning in a Taiwanese Classroom
}

\author{
Bor-Tyng Wang
}

\begin{abstract}
It is never a matter for human beings possessing creativity, but a matter of having much or less of it. Creativity is like intelligence, some people are rich in creativity, yet some lack a bit. Scholars have mentioned that Taiwan's traditional teaching method emphasizes on memorizing facts and knowledge, but neglects the enlightening of problem understanding and creative thinking. In addition, in recent years, learning computer programming has become a global trend. Educational institutions in various countries have promoted computer programming in schools. Hence, this study wants to use the cognitive apprenticeship approach and the collaborative learning in an Apps design class in the university. The study focuses on investigating students' attitudes toward the course design. The findings suggest that students' interests and motivation have been increased through the proposed approach. These findings have implications for teachers who are teaching computer programming.
\end{abstract}

Index Terms-Computer programming, cognitive apprenticeship approach, collaborative learning.

\section{INTRODUCTION}

In recent years, learning computer programming has become a global trend [1], [2]. Educational institutions in various countries have promoted computer programming in elementary and junior high school [3]. Some researchers believes that the goal of learning programming is not just to learn the skills of writing programs. They think that another goal of learning programming is to let learners understand how to use computer programs to improve problem process capability [4], [5].

Therefore, the Ministry of Education in Taiwan has actively incorporated computer programming into the required course of the National Junior and Senior High Schools. The United States has also incorporated computer courses into general education and increased computer education budget. All countries are actively training software design talents because it is the key to the success of personal employment, and industrial transformation upgrading [6].

However, while taking the computer programming courses, Taiwanese college students often encounter the following difficulties in learning computer programming [7]:

1) When teaching in large classes, it is difficult for teachers to provide immediate individual guidance to students. Allow students to solve problems with their own logic is difficult to increase the willingness to actively study

Manuscript received May 2, 2018; revised October 12, 2018.

The author is with Feng-Chia University, Taiwan (e-mail: btwang.tw@gmail.com) because of the lack of assistance from others.

2) It is difficult for students to use or understand the mistakes if their practice is based on examples.

3) Syntax errors often get students into trouble. It always leads to poor learning result because the students are unable to solve problems.

In order to solve the difficulties, the proposed study uses the cognitive apprenticeship approach and collaborative learning in a freshman Apps class in Taiwan. The study wants to investigate the following questions:

1) Do students' attitudes toward Apps learning after taking the designed course?

2) How do the students' attitudes toward collaborative learning change after taking the course?

\section{LITERATURE REVIEW}

In this section, the cognitive apprenticeship approach and collaborative learning are introduced.

\section{A. Cognitive Apprenticeship Approach}

The cognitive apprenticeship approach is originated from the situated cognitive theory [8], which believes that knowledge skills require a real situation to be learnt, and the learnt skills also should be used in real situations. In an ideal learning environment, the cognitive apprenticeship teaching method includes the characteristics: modelling, coaching, scaffolding and fading, articulation, reflection, exploration [8]-[10]. The explanations of the characteristics are as follows.

\section{1) Modelling}

Modelling is to concretize the concept of the teacher's research, so that students can clearly understand what they are learning. For example: the instructor will operate him/herself while the students observe. Next, the instructor will pick a topic for the students, then construct the concept map him/herself, to fully present the thoughts of through the idea's research.

\section{2) Coaching}

Coaching is to observe the students during operation, and provide them hints, scaffolds, feedbacks, demonstration, reminders and assignments on new objectives. For example: have students read related documents and write abstracts. Thereby let the students develop their ability to refine referenced articles quote correctly. Then develop their explaining skills by having them take turns doing oral presentations, thereby the students learn as they also tech, 
and strengthen the concepts. Finally, guide the students to notice context they haven't noticed before when observing them do research.

\section{3) Scaffolding and fading}

Scaffolding is to provide assistance to the students when operating. After the scaffold has been constructed, choose the right time to fade out so the students can be independent. Explanations are as follows.

1) The instructor provides blueprints of the project for students to imitate the format.

2) The instructor discusses with the group about the outline and structure.

3) The instructor should fade out when he diagnoses that the students begin to operate experiments correctly, thus let the students work independently. Or when he determines that the students have built up the structure of the research's outline, thus fade out from assisting them build up the structure.

\section{4) Articulation}

Instructors can train students to connect their research's fragments through debates, reports on progress rate and real-time Internet meetings. Through debates and reports, the students can understand their topic and the correct progress to solve problems.

\section{5) Reflection}

Reflection means to let students compare their solutions to experts and other students. The instructor should adopt the methods as explained.

1) Co-directing strategies

2) Analyzing outstanding works

\section{6) Exploration}

Exploration is to push students into a problem solving pattern. The instructor can assist students to adapt this pattern by the following methods. First, provide students research topics at first, then have the students collect information on topics of their own interest, thus form the students' sub-topic of interest. Don't answer the students' questions right away. The instructor should only hint the students' tips at most. Finally, provide similar examples, ask them to imitate, through the imitation process they can adapt the problem solving pattern.

\section{7) Set a deadline}

Pressure the students with the deadline to stimulate their potential, perhaps making them adapt the pattern.

\section{B. Collaborative learning}

Collaborative learning is a type of teaching strategy [11], [12]. Learning groups gain personal accomplishment through the process of group interaction, dependence, and competition, in order to reach their set goal. To realize the thesis, teachers have to prepare well-designed teaching materials, and provide proper inducement; as for the learning groups, they need to cooperate and interact in order to raise individual member's self-learning motivation [12], [13]. Collaborative learning can create an energetic and active learning atmosphere, and group discussions will stimulate students' thinking; role distribution provide lower level students opportunities to participate, enhance their interest about the subject, and gradually improve their learning attitude [13]. Different students have different talents, they can have a wide range of contribution during learning activities, and gain different knowledge while learning. Inevitably, students would encounter difficulties and cognitive conflicts, they will need to solve their problems by discussing, interacting, and communicating with each other.

In most researches, collaborative learning has significant advantages than individual learning for the following reasons [14]-[16]:

1) For students who have lower achievement, collaborative learning can enhance students' high-level cognitive performance in the condition of clear reflection system, highlighted personal responsibility, and structured strategies.

2) On the aspect of high-level cognitive, collaborative learning can enhances students' high-level cognitive.

3) It may have a better chance of widening and broadening students' thinking level.

In groups, students will have more chance to share and discuss thoughts with others, thus having different opinions to improve essay content or technique to clarify or complete their work.

Group discussion can also help students organize their personal thoughts. In group interaction, students must organize their thoughts before they express their opinions in order to express their opinions in an organized way. This ability of organizing words in advance in the brain helps students organize structures and arrange ideas.

Moreover, collaborative learning can reduce student's anxiety [17]. Before students start their tasks, they have adequately discussed about the topic so that they have a clearer understanding of what to do. In addition, with the support and encouragement of the group members, students will have their insecure feeling of doing the work, and helplessness of doing on their own reduced.

In addition, healthy competition among peers is conducive to the improvement of students' creativity [18]. Creative thinking teaching is based on students. Therefore, participation should be encouraged in the activities so that students can place themselves in class, with a sense of participation and responsibility. Students keep thinking, and then draw more ideas from their thinking, virtually improving students' writing creativity.

\section{METHOD}

In this section, the research design, participants and instruments are introduced.

\section{A. Research Design}

The study was designed to answer the following question:

1) Do students' attitudes toward Apps learning after taking the designed course?

2) How do the students' attitudes toward collaborative learning change after taking the course?

The author investigated these questions by distributing a self-developed questionnaire called "College Student's Attitudes towards Apps learning" both at the beginning and at the end of the Apps class within 9 weeks. The Apps design 
class is based on the cognitive apprenticeship approach. First, the author showed the models on App Inventor 2 to the whole class. Then the author let students make their own Apps and coached them. After that, through the scaffolding process, students learn and practice what they have learned from the teacher. Finally, during the reflection phase, students were able to show their Apps to the whole class in the final in-class presentation.

\section{B. Participants}

A total of twenty-nine international students (13 women, 16 men) from seven different countries took the Apps design course. All reported they had never learned how to write the Apps program before.

\section{Instruments}

In this study, the research tool was the five-point Likert scale questionnaire consisted of two sections with 14 items. The first section asked the respondents to fill out their personal information and section 2 focused on attitudes regarding the attitudes toward Apps design class. The reliability of the questionnaire was acceptable (Cronbach's alpha=.711).

\section{RESUlTS AND DisCUSSIONS}

In this study, twenty-nine questionnaires were distributed at the beginning and at the end of the Apps design class, and all of the questionnaires were returned.

The Apps design course is a basic course to let students understand the interface, function, components and blocks of App Inventor 2. The teacher assigned the class into six different groups. Besides, the design of the lesson plan was based on the cognitive apprenticeship approach. That is, students really did the real project and they learned how to make their final project step by step.

TABLE I: RESUlTS OF COLLEGE STUDENT'S ATTITUDES TOWARDS APPS LEARNING

\begin{tabular}{|c|c|c|}
\hline Items & MD & $S D$ \\
\hline $\begin{array}{l}\text { 1. Learning Apps makes my friends think I am } \\
\text { awesome. }\end{array}$ & .208 & .329 \\
\hline $\begin{array}{l}\text { 2. I only care about if I can get good grades in this } \\
\text { course. }\end{array}$ & -.125 & .264 \\
\hline $\begin{array}{l}\text { 3. I think learning Apps is very important because } \\
\text { I can use it in everyday life. }\end{array}$ & -.041 & .194 \\
\hline $\begin{array}{l}\text { 4. I think learning Apps is important because it } \\
\text { stimulates my logical thinking. }\end{array}$ & .291 & .185 \\
\hline $\begin{array}{l}\text { 5. I think learning Apps is important because I can } \\
\text { learn how to solve problems. }\end{array}$ & .375 & .267 \\
\hline 6. I think learning Apps is easy. & .750 & .264 \\
\hline 7. I think I can write Apps. & .833 & .338 \\
\hline 8. I am confident that I can debug. & .291 & .348 \\
\hline $\begin{array}{l}\text { 9.I think I try my best to finish App homework } \\
\text { with my classmates. }\end{array}$ & .250 & .235 \\
\hline $\begin{array}{l}\text { 10. I enjoy exchanging others' opinions and } \\
\text { absorbing them. }\end{array}$ & -.208 & .225 \\
\hline $\begin{array}{l}\text { 11. I prefer to do the project myself, and do not } \\
\text { want to spend time with people. }\end{array}$ & .500 & .262 \\
\hline $\begin{array}{l}\text { 12. This course can approve my problem-solving } \\
\text { abilities. }\end{array}$ & .291 & .251 \\
\hline $\begin{array}{l}\text { 13. I think implementation courses as a waste of } \\
\text { time. }\end{array}$ & .500 & .208 \\
\hline $\begin{array}{l}\text { 14. I will do my best to complete projects to view } \\
\text { my achievements. }\end{array}$ & .833 & .189 \\
\hline
\end{tabular}

The results of the questionnaire "College Student's Attitudes towards Apps learning" can be summarized as follows. The data were collected and then the mean difference (MD) were calculated by paired-samples T test, SPSS 20. The scale and the results are shown in Table I.

According to the results in Table 1, the author found some interesting points:

1) Students would try their best to complete the Apps project (Q14), and they are confident that they can write the Apps (Q7) have the greatest positive gap. Hence, the students are confident to do Apps design after taking the course. Moreover, the result of item 8 and item 9 both supported the idea.

2) Item 10 'I enjoy exchanging others' opinions and absorbing them" had the greatest negative gap. Moreover, item 11 showed that students were willing to do the Apps project on their own instead of working with others. Because this is a class with international students from seven different countries, students may have some language barriers which cause them want to do the project on their own. It is the communication problem. To solve the problem, maybe the teacher can divide the groups based on students' nationalities next time.

3) Students do feel they make a progress in their problem-solving abilities and logical thinking abilities (see item 4 , item 5 \& item 12).

4) Many students felt confident in debugging programs, which increases their willingness to learn computer programming (item 8 ).

At the beginning, students lack positive attitude and confidence. Although college students think that the program design ability is very important, their willingness to learn is not high, and their self-confidence in learning computer programming courses is also insufficient. The reason for this situation is that traditional educators often teach in a one-way manner since the educators want to teach the most knowledge to students in the shortest time because of the teaching progress. Thus, students lack the opportunity to practice independent thinking. When they encounter problems, they always expect that the educators can directly tell the answer or keep counting on luck. Therefore, when encountering the subjects that require thinking, they often do not dare to try easily. That is the reason why students cultivate the fluke mind of passive learning.

\section{CONCLUSIONS}

If college students have a high level of learning motivation for computer programming courses, it will affect the use of their learning strategies. Based on the findings of the study, the conclusions can be summarized as follows.

1) The existence of learning motivation is the critical factor which influences learners' arrangement and plan for their learning strategies. In this study, there is a positive change in students' attitudes towards Apps learning. Therefore, it is recommended that universities should create a good learning environment for computer programming to help stimulate college students' motivation for learning computer programming. If students have a positive learning attitude, then they can get the optimal 
effectiveness of computer programming in the good learning environment. At the same time, it is suggested that undergraduates should try different learning strategies when they are learning computer programming, and find out the best way for them to learn computer programming courses.

2) As for students' collaborative learning attitudes, there is no significant change. The author thinks maybe it is because they are international students and there are some language barriers. In addition, the culture differences may be another reason causing the inefficient collaborative learning.

In addition, there are some teaching suggestions for future studies.

1) Improve the university programming learning environment. Suggest schools to create programming courses through progressive mode to increase the opportunities for peer discussions. In addition, schools can often hold programming lectures or related competitions and encourage students to participate.

2) Form a professional community. Mutual learning between teachers and students is also a kind of professional growth. It is suggested that schools can form professional communities and enhance the motives of college students' learning.

3) Activated teaching methods. Teachers are suggested to use subject-based learning or problem-oriented teaching methods to emphasize basic concepts and problem-solving learning and improve students' cognitive barriers to computer programs.

\section{APPENDIX}

The following are Apps designed by the international students. For example, the students from Thailand designed the app to introduce Feng-chia night market in Taichung (see Fig. 1).

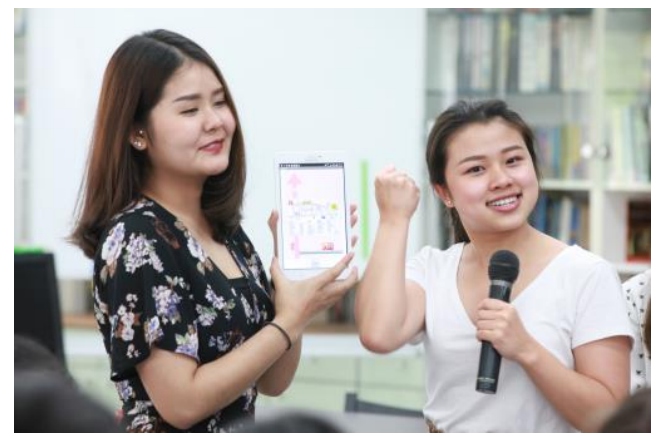

Fig. 1 App — night market introduction.

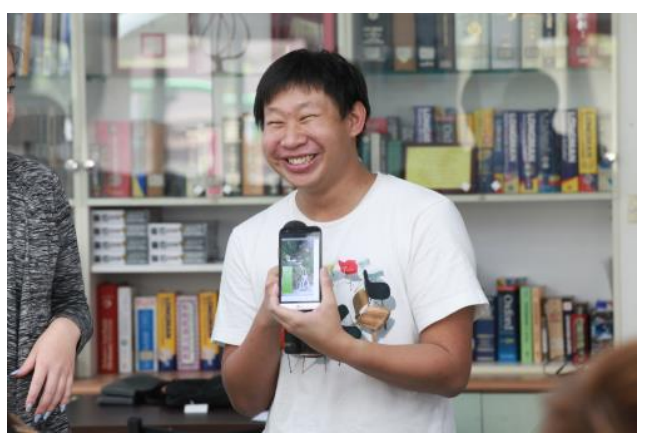

Fig. 2. App—introducing Taroko National Park.
There is another student from Thailand designed the app to introduce a famous tourist attraction "Taroko National Park" (see Fig. 2).

Still, some students from Indonesia designed the app of Bali island (see Fig. 3) and students from Mongolia designed the app to introduce Mongolia (see Fig. 4).

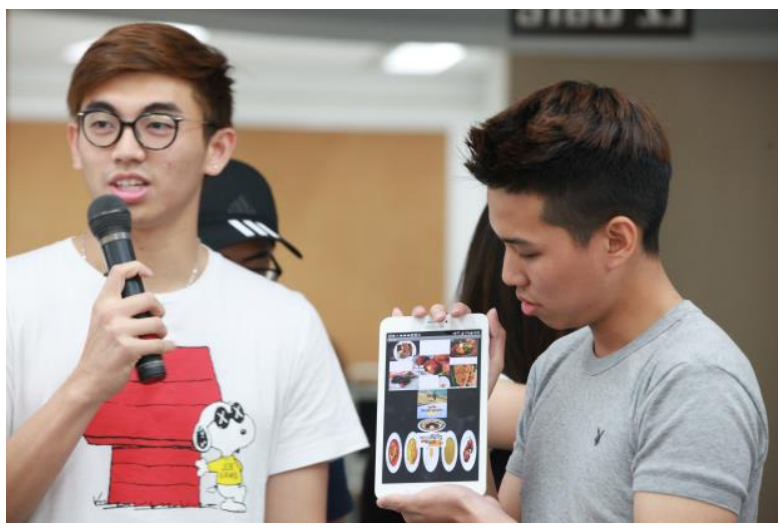

Fig. 3. App - introducing Bali island.

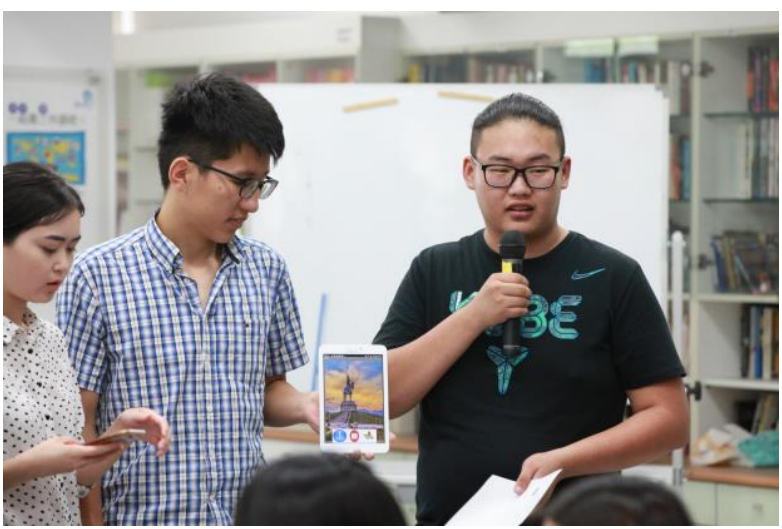

Fig. 4. App-introducing Mongolia.

\section{REFERENCES}

[1] S. Martin, G. Diaz, E. Sancristobal, R. Gil, M. Castro, and J. Peire, "New technology trends in education: Seven years of forecasts and convergence," Computers \& Education, vol. 53, no. 3, pp. 1893-1906, November, 2011.

[2] B. Boehm, "A view of 20th and 21st century software engineering," in Proc. the 28th International Conference on Software Engineering, China, pp. 12-29, 2006.

[3] A. V. Aho, "Computation and computational thinking," Computer Journal, vol. 5, pp. 832-835, 2012.

[4] P. C. Sun, R. J. Tsai, G. Finger, Y. Y. Chen, and D. Yeh, "What drives a successful e-Learning? An empirical investigation of the critical factors influencing learner satisfaction," Computers \& Education, vol. 50, no. 4, pp. 1183-1202, May 2008.

[5] N. Parsazadeh, R. Ali, and M. Rezaei, "A framework for cooperative and interactive mobile learning to improve online information evaluation skills," Computers \& Education, vol. 120, pp. 75-89, May 2018.

[6] E. G. Carayannis, D. Popescu, C. Sipp, and M. Stewart, "Technological learning for entrepreneurial development (TL4ED) in the knowledge economy (KE): Case studies and lessons learned," Technovation, vol. 26, no. 4, pp. 419-443, April 2006.

[7] H. K. Wu, S. W. Y. Lee, H. Y. Chang, and J. C. Liang, "Current status, opportunities and challenges of augmented reality in education," Computers \& Education, vol. 62, pp. 41-49, March 2013.

[8] J. S. Brown, A. Collins, and P. Duguid, "Situated cognition and the culture of learning," Educational Researcher, vol. 18, no. 1, pp. 32-42, January 1989.

[9] A. Ghefaili, "Cognitive apprenticeship, technology, and the contextualization of learning environments," Journal of Educational Computing, Design \& Online learning, vol. 4, 2003. 
[10] A. Collins, J. S. Brown, and A. Holum, "Cognitive apprenticeship Making thinking visible," American Educator: The Professional Journal of the American Federation of Teachers, vol. 15, no. 3, pp. 6-11, 1991.

[11] M. Alavi, "Computer-mediated collaborative learning: an empirical evaluation," MIS Quarterly, vol. 18, no. 2, pp. 159-174, June 1994.

[12] P. Resta and T. Laferrière, "Technology in support of collaborative learning," Educational Psychology Review, vol. 19, no. 1, pp. 65-83, March 2007.

[13] S. Yamarik, "Does cooperative learning improve student learning outcomes?" The Journal of Economic Education, vol. 38, no. 3, pp. 259-277, 2007.

[14] A.A. Gokhale, "Collaborative learning enhances critical thinking," Journal of Technology Education, vol. 7, no. 7, April 1995.

[15] C. Pang, J. Lau, C.P. Seah, L. Cheong, and A. Low, "Socially challenged collaborative learning of secondary school students in Singapore," Educ. Sci., vol. 8, no. 1, 2018.

[16] G. J. Hwang, Y. R. Shi, and H. C. Chu, "A concept map approach to developing collaborative Mindtools for context-aware ubiquitous learning," British Journal of Educational Technology, vol. 42, no. 5, pp. 778-789, September 2011.
[17] M. Toyama and K. Mori, "Reducing student anxiety: The effects of collaborative learning through computer conferencing," International Journal of Information and Education Technology, vol. 7, no. 2, pp. 905-908, December 2017.

[18] R. Donnelly and T. Barrett, "Encouraging student creativity in higher education," in B. Higgs \& M. McCarthy (Eds.), Emerging Issues II: The Changing Roles and Identities of Teachers and Learners in Higher Education, Cork:NAIRTL.

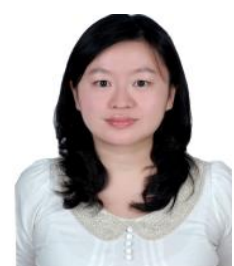

Bor-Tyng Wang is currently an associate professor of Foreign Language Center at Feng-Chia University, Taiwan. She received her Ph. D. degree in Graduate Institute of Educational Measurement and Statistics from National Taichung University of Education, Taiwan. She likes to apply teaching theories to the practical teaching and enjoys trying to teach in innovative ways. Her research interests include English language teaching, language assessment and CALL. 